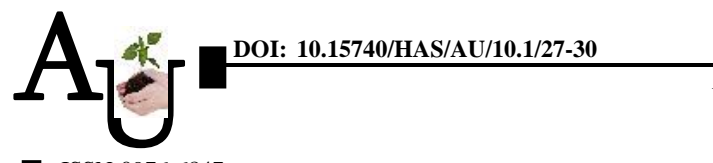

a ISSN-0976-6847

\title{
Research Article: Relationship between personal, social, economic, communicational and psychological characteristics and involvement of men and women in paddy and sugarcane crops cultivation
}

\author{
PARMESHWARI B. PAWAR* AND R.D. PANDYA
}

ArTiCLe Chronicle :

Received :

05.12.2014;

Revised :

26.12.2014;

Accepted :

12.01.2015

KeY Words : Correlation, Personal, social communicational and psychological characteristics, Involvement in paddy, Sugarcane crops cultivation
Author for correspondence :

\section{PARMESHWARI B.}

\section{PAWAR}

Department of Extension Education, K. K. Wagh College of Agriculture, Sarswatinagar, Panchavati, NASHIK (M.S.) INDIA

Email:pari2805@ rediffmail.com

See end of the article for authors' affiliations
SUMMARY : The age of men and women, education of men and women, type of family of women, occupation of men and women, annual income of men, land holding of man, farming experience of men and women, social participation of men and women, innovativeness of men and women, training received by men and women, economic orientation of men and women, scientific orientation of men and women, risk orientation of men and women, management orientation of men and women, progressivism of women and achievement orientation of men and women, had highly significant correlation with their involvement in paddy cultivation while, progressivism of men was found significant with their involvement in paddy cultivation. Incase of annual income and land holding of women had negative but highly significant association with their involvement in paddy cultivation. However, age of men and training received and education of women were found significant. Incase of family type of men, annual income of women and land holding of women was negative but significantly associated with their involvement in sugarcane cultivation.

How to cite this article : Pawar, Parmeshwari B. and Pandya, R.D. (2015). Relationship between personal, social, economic, communicational and psychological characteristics and involvement of men and women in paddy and sugarcane crops cultivation. Agric. Update, 10(1): 27-30. 